\title{
US plans to protect clinical research participants
}

Officials in the US Department of Health and Human Services (HHS; Washington, DC), led by HHS Secretary Donna Shalala, announced several new measures in late May to better protect individuals who participate in clinical research and to strengthen federal oversight of researchers and institutions that are involved in such activities. The proposals fall into five categories, touching on education and training, informed consent, improved monitoring, conflicts of interest and, remarkably, civil money penalties. Although several stages away from implementation, it is the threat of fines for researchers that is provoking loudest objection from both academia and industry.

The administration promises to seek new legislative authority for imposing civil monetary penalties on those who flagrantly violate federal regulations. HHS will ask Congress for authority to impose fines of up to $\$ 250,000$ on individual researchers and $\$ 1$ million on institutions "for repeated violations" of federal rules, according to HHS Deputy Assistant Secretary for Science Policy William Raub. He is one of several administration officials, industry representatives, and university researchers who appeared before the Senate Committee on Health, Education, Labor and Pensions Subcommittee on Public Health, chaired by Sen. Bill Frist (R-TN), on May 25 to discuss these new measures.

Regulatory officials in the US Food and Drug Administration (FDA; Rockville, MD) would have responsibility for imposing and collecting such fines, according to Raub. Although the agency "can currently issue warning letters or impose regulatory sanctions that halt research until problems are rectified," he says, being able to exact financial penalties would give the agency "additional tools..." Having authority to threaten potential violators with fines not only would give the agency more clout, but this power would provide FDA with a greater degree of deftness in ongoing efforts to protect patients in clinical trials, adds Kathryn Zoon, director of the FDA Center for Biologics Evaluation and Research.

Not surprisingly, neither industry representatives nor university-based researchers are very keen about the possibility of facing federally sanctioned monetary penalties. Pamela Zeitlin, who oversees cystic fibrosis gene therapy clinical trials at Johns Hopkins University (Baltimore, MD), says these additional sanctions not only are not needed, but they would discourage young scientists and physicians from pursuing careers in clinical research.

Lisa Raines, a senior vice president for Genzyme Corp. (Cambridge, MA), is more blunt. "In our view, [the] proposal that Congress grant FDA authority to impose civil money penalties lacks merit," she says. Congress rejected a similar proposal several years ago, she notes, arguing that it should be "rejected again." She agrees with Zeitlin that FDA's current capacity to halt clinical trials already gives it plenty of authority to safeguard human subjects.

Although the death of a young man who participated in gene therapy research experiments at the University of Pennsylvania (Philadelphia, PA) last year (Nat. Biotechnol. $18,143,2000)$ played a key role in prompting these new measures, they are by no means restricted to gene therapy. But in the case of gene therapy, Raines also points to the need for clinical investigators and their sponsors to meet "conflicting adverse event reporting requirements by two different federal agencies" as an ongoing problem of considerable importance. Currently, gene therapy investigators supply somewhat different adverse event reports to officials at both FDA and the National Institutes of Health (NIH; Bethesda, $\mathrm{MD})$. "While the highest priority is to eliminate inconsistent reporting requirements," she says, "it is not clear that providing duplicate reports to both NIH and FDA is an optimal approach either.... It is our view that FDA should remain the agency with regulatory authority, while [the NIH] Recombinant DNA Advisory Committee should maintain its important role as an educational and advisory body." (see p. 700)

According to Raub, under the HHS proposals, NIH will require all investigators-not only those involved in gene therapy-to submit "clinical trial monitoring plans" for phase
I and II trials to NIH and to their respective institutional review boards for review, and they will need to supply those review boards with results "as frequently as necessary to help ensure subjects' protection.” An even more elaborate system is to be in place for phase III trials, and FDA is to issue guidelines explaining how requisite monitoring efforts are to be coordinated, he says. Although the details remain fuzzy, the plan calls for closer collaborations between NIH and FDA when it comes to monitoring of clinical trials and reporting of adverse events.

Also of importance to the biotechnology industry - but also still vague because details are yet to be developed-NIH plans to "issue additional guidance" and HHS will convene "public discussions this summer to find new ways to manage financial conflicts of interest so that research subjects are neither misled nor coerced, and to do more toward ensuring that research results are analyzed and represented objectively," Raub says. "Based on these public forums, NIH and FDA will work together to develop new guidance for the medical research community."

NIH's current conflict of interest guidelines outline thresholds that it considers "significant," but does not prohibit, including an individual holding a $5 \%$ or higher interest in a company, or an equity interest of $\$ 10,000$ or more, or earning that figure as a consultant. Coming to any uniformity or agreement could be quite a challenge as universities and other research institutes typically have devised different rules of their own.

Jeffrey L. Fox

\section{Human Research Protections Office created}

Also in June, the HHS set up a new Office for Human Research Protections (OHRP; Washington, DC) to help implement the patient protection measures announced by Donna Shalala. OHRP replaces the Office for Protection from Research Risks (OPRR) that was part of the National Institutes of Health. Last year, a top-level advisory group recommended to former NIH Director Harold Varmus that OPRR, which had jurisdiction over a wide range of $\mathrm{NIH}$-supported research, be moved to HHS. That group also recommended that other steps be taken to ensure that it be seen as an independent entity with adequate resources, stature, and oversight. As a result, "the new office will have increased resources and broader responsibility," says Surgeon General David Satcher, who in his capacity as HHS Assistant Secretary for Health will oversee the new office.

OHRP takes on near federal-wide responsibility, with jurisdiction over some 17 agencies that conduct research involving human subjects. Even with the new structure, however, officials at the Food and Drug Administration (Rockville, MD) will retain authority to enforce patient protections in clinical trials to evaluate new therapeutic products and medical devices, according to Satcher. "The new organizational structure will enable more effective coordination."

Edward Greg Koski has been appointed director of OHRP. Koski comes to HHS from Harvard Medical School (Boston, MA) and Partners HealthCare System (Boston, MA), where he was responsible for overseeing patient protections within a consortium of institutions conducting biomedical research involving human subjects. 